〔ミニレビュー〕

\title{
泌乳持続性という新しい選抜形質について
}

\author{
富樫研治
}

(独) 北海道農業研究センター

\section{New selection trait of lactation persistency}

\section{Kenji TOGASHI}

Agricultural Research Center for Hokkaido Region

\section{1. 泌乳持続性の定義}

従来の 305 日乳量や体型以外に酪農経営の安定や消 費者の酪農への賛同を得る動物福祉に貢献する新しい 乳牛の改良形質の一つとして、泌乳持続性について紹 介する。新しい形質による選抜は、近交係数 (Young と Seykora 1996; 河原ら 2002 表 1) が上昇する現状に おいて、従来と異なる新しい遺伝資源からの選抜を意 味し近交増加の抑制にも貢献する。泌乳持続性とは、 ピーク乳量を持続する能力で、一定期間における総乳 量が同じ条件で、ピークからの乳量の低下が少ない場 合を泌乳持続性が高い、低下が大きい場合を泌乳持続 性が低いと表現する。図 1 にTogashi ら (2008a) が調べ た我が国の1、2、3 産の305日までの検定乳量をもつ 乳牛、約 1 万頭の 15 日移動平均を示した (305 日平均
乳量：初産 $8,000 \mathrm{~kg} 、 2$ 産 9,500 kg、3 産 9,850 kg)。初 産の泌乳曲線では、ピーク以降の乳量低下が少ないが、 2、3 産と進むにつれてピーク以降の乳量の低下が大き くなる。このように泌乳持続性は初産が最も高く、産

表 1.アメリカと日本の近交倸数

\begin{tabular}{lll}
\hline 年 & アメリカ & 日本 \\
\hline 1970 & 2.7 & 0.87 \\
1980 & 4.6 & 1.27 \\
1990 & 5.4 & 1.91 \\
2000 & 6.8 & 2.33 \\
2010 (理論値) & 8.2 & $(4.88,2004)$ \\
2020 (理論値) & 9.7 & \\
\hline
\end{tabular}

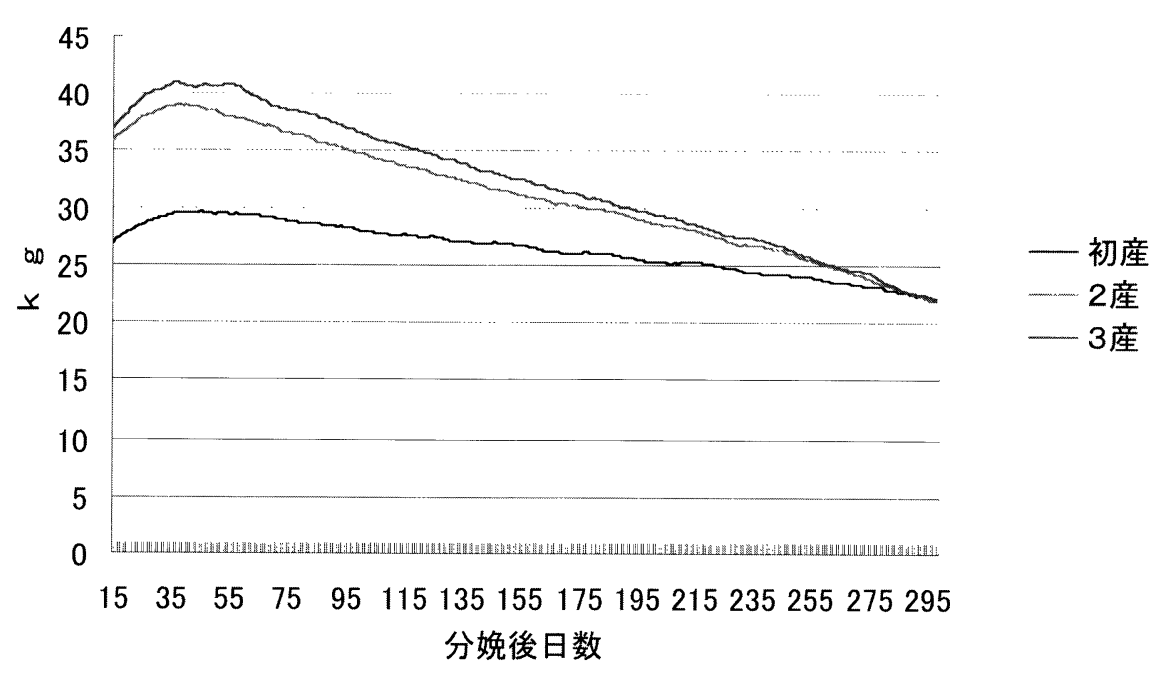

図1. 初産から 3 産までの泌乳曲線 
次が進むにつれて低下する。ピーク日は $1 、 2 、 3$ 産そ れぞれ、分婏後 45、40、36 日となり、泌乳持続性が 大きいほど、ピーク日は遅れる傾向があり（図 1、表2）、 泌乳持続性とピーク日の遺伝相関は 0.54 と高い（Muir ら 2004)。乳量の改良を305 日等の総乳量だけでなく、 途中の乳期の進行に伴う総乳量の再分配という新しい 泌乳持続性から導かれる概念を導入し、飼養管理の効 率化、繁殖障害を含む周産期病の抑制など、より省力 的、効率的で健全な酪農への貢献が期待できる。

\section{2. 泌乳曲線の生理的メカニズム}

泌乳曲線は、乳腺上皮細胞数とその個々の細胞の活 性度によって決まる(Capuco ら 2003)。牛では泌乳前 期の泌乳曲線の形は、個々の乳腺上皮細胞の活性度、 泌乳中後期の泌乳曲線の形は、細胞数そのものの影響 が大きい (Capucoら 2001)。ピーク日以降の乳量の低 下は、アポトーシスによる乳腺上皮細胞数の減少の影 響が大きく、また、乳腺間質系細胞と乳腺上皮細胞の 和からなる全ての細胞中の、乳腺上皮細胞の割合は、 分婏後 $83 \%$ と高いが、泌乳後期には $74 \%$ に減少する （Capuco ら 1997）。乳期全体を通して分娩後に作られ た乳腺上皮細胞数は、分婏後にあった細胞数の $50 \%$ に 達し、泌乳末期に存在する乳腺上皮細胞の全ては、分 娩後に作られたものと考えられる(Capucoら 2001)。 乳腺上皮細胞数は、細胞の増殖とアポトーシスによる 細胞死の相対的な結果であり、増殖と細胞死は同時に 進行している(Wilde ら 1987; Knight 2000)。乳腺細胞 の增殖率は $0.3 \% /$ 日、アポトーシス率は、0.56\%/日 といわれる(Capuco ら 2001)。したがって、ピーク以 降の乳量低下が少ない泌乳持続性の高い牛は、アポ トーシスによる細胞死が少なく乳腺上皮細胞数が多く 維持される牛と考えることができる。泌乳初期の細胞 の増殖はエネルギーが関与し、低エネルギー状態では その増殖が低下する (Capuco ら 2001; Sorensen ら
2000：Capuco と Byatt 1998)。泌乳初期に 6 回 / 日搾乳 した牛は、3 回搾乳にしてもピーク以降も乳量の低下 が少なく高乳量を維持した (Bar-Peled ら 1995)。この ように、搾乳刺激は乳腺の成長を促すといわれている (Knight と Peaker 1984; Capuco と Akers 1990)。乳腺上 皮細胞数が多回搾乳という搾乳刺激によって増加した ものと推察される。

成長ホルモンは、それ自身が乳生産に関与する (Gallego ら 2001; Sinowatz ら 2000; Yang ら 2000)のみ ならず、肝臓や乳腺等の末梢組織で乳腺上皮細胞の増 殖に関与する IGF-1（インシュリン様成長因子 1)の遺 伝子発現を促進させる (Hadsell ら 2002)。IGF-1 濃度は、 泌乳初期、ピーク、後期に移行するにつれて高くなり、 IGF-1 は泌乳持続性向上に関与している (Miller ら 2001)。bST 処理は、泌乳持続性を上昇させる (Phipps ら 1991; Van Amburgh ら 1997; Bauman ら 1999)。これ は、bST が乳腺上皮細胞の活性ではなく細胞数の増殖 に関与し、乳腺上皮細胞数を維持することによる (Capuco ら 2003)。IGF-1 は、反アポトーシス作用をも ち、乳腺上皮細胞の生存性に関与する(Flint ら 2001)。 長日処理は、泌乳持続性を高める (Capuco ら 2003) が、 それはIGF-1 の増加と関連している(Dahlら 1997; Dahl ら 2000)。IGF-1 の作用は、そのレセプターに IGFBP5 という蛋白が結合すると抑制されるため、 IGFBP5 の増加は乳腺上皮細胞のアポトーシスを促進 することになる (Stefanon ら 2002)。プロラクチンは IGFBP5 の合成を抑制することにより、間接的にアポ トーシスを抑制する(Flint ら 2001；Stefanon ら 2002）。 また、プロラクチンレセプターの感受性は多回搾乳に より高まる(Stefanon ら 2002)ことが、多回搾乳による 乳腺上皮細胞増加の一つの要因になっていると考えら れる。その他にもプロジェステロンは、子宮において マトリックスメタロプロテアーゼ (MMP) の発現を抑 制する (Hulboy ら 1997) が、乳腺においても同様な機

表 2. 1，2，3 産の泌乳曲線パラメー夕（Togashi ら 2008a）

\begin{tabular}{cccccccc}
\hline 産次 & 頭数 & 検定記録数 & 検定日平均乳量 & ピーク日 ${ }^{1}$ & ピーク乳量 $^{1}$ & 280 日乳量 ${ }^{1}$ & 泌乳持続性 $^{2}$ \\
\hline 1 & 10400 & 82737 & $26.2 \pm 5.75$ & 45 & 29.5 & 22.8 & -6.7 \\
2 & 10408 & 80532 & $31.1 \pm 8.29$ & 40 & 38.9 & 23.2 & -15.7 \\
3 & 10288 & 75450 & $32.3 \pm 9.25$ & 36 & 40.8 & 23.4 & -17.4 \\
\hline
\end{tabular}

${ }^{1} 15$ 日移動平均による

2 泌乳持続性：280日乳量ーピーク乳量 
作が考えられる (Stefanon ら 2002)。MMP は、基底膜 の分解に関与するので、それが抑制されることはアポ トーシス抑制にも関与していると考えられる。

不完全搾乳は、乳腺上皮細胞への血流が抑制され酸 素の供給が少なくなりアポトーシスの誘因となる (Capuco ら 2003)。酸化ストレスは、アポトーシスに 対する感受性を上げる (Hockenbery ら 1993)。乳腺で アポトーシス化した細胞では、ミトコンドリアDNA の損傷や酸化グルタチオンの存在が示されている (Esteve ら 1999)。このアポトーシスはbcl-2 遺伝子群 によって緩和される (Hockenbery ら 1993; Hochman ら 1998)。アポトーシスに関与する要因は他にも多くの ものが考えられる。過剩な窒素肥料の施肥により牧草 中の硝酸塩が増え、それが乳牛の体内で強力な酸化物 質であるペルオキシナイトライトに転換する可能性も あるといれている(Radi ら 1991；Beckman ら 1994）。 p53 腫瘍抑制遺伝子は、アポトーシスを誘因するとい われ、BaxやFasのアポトーシス促進遺伝子の転写促進、 アポトーシス抑制遺伝子である bcl-2 遺伝子群の転写 抑制に関与する (Jerry ら 2002)。泌乳中後期は、妊娠 期でもある。妊娠 100 日位以降、胎盤からエストロジェ ンが分泌され乳生産にマイナスの影響を及ぼすといわ れ（Bachman ら 1988) 泌乳持続性低下の要因となる。

乾乳期は、MMPが活性化され (Stefanon ら 2002) 老 いた乳腺上皮細胞を自らが死に至らしめると同時に新 しい細胞を増殖させるステージである。乾乳期間中は 乳生産は犠牲になるが、次の泌乳再開に向けた適応期 間といえる。乾乳期間を設けなかった場合は、乳腺の 間質系細胞と上皮細胞との和である細胞数は、乾乳期 を設けた場合に比べ、同じであるが、乳腺上皮細胞数 の割合は減少する (Capuco ら 2003)。なお、17 $\beta$-工 ストラジオールの乾乳前投与により乳腺上皮細胞の退 化が促進される (Athie ら 1996；1997)。

泌乳持続性に関与している遺伝子として、DGAT1 の 多型が乳蛋白量の持続性に関与しているとする報告が ある（Harder ら 2006）。また、Sharma ら (2006)は、第 8 染色体末端にある炎症性に関与するレセプター遺伝 子 (TLR4)の SNP 多型と泌乳持続性の関連を調べ、遺 伝子型により泌乳持続性が変わるとし体細胞スコアー （SCS）との関連でもSCS が低い牛は泌乳持続性が高い 遺伝子型を有しているとした(表3)。

これらのことから泌乳持続性の向上は、酸化ストレ スがかからず、負のエネルギーバランスにならない栄 養管理、長日処理、多回搾乳や不完全搾乳を導かない 搾乳管理という飼養管理の工夫により bSTなど、ホル
表 3. 第 8 染色体末端にある炎症性に関与するレセプ 夕ー遺伝子 (TLR4)の多型

\begin{tabular}{|c|c|c|c|}
\hline \multirow[b]{2}{*}{ SNP } & \multirow[b]{2}{*}{ 遺伝子型 } & \multicolumn{2}{|c|}{ 形 質 } \\
\hline & & 泌乳持続性 (\%) & SCS \\
\hline \multirow[t]{3}{*}{$\mathrm{P}-226$} & $\mathrm{CC}$ & 65.87 & - \\
\hline & $\mathrm{CG}$ & 67.20 & - \\
\hline & GG & 67.25 & - \\
\hline \multirow[t]{3}{*}{$E 3+1656$} & $\mathrm{CC}$ & 67.17 & - \\
\hline & CT & 67.14 & - \\
\hline & TT & 66.00 & - \\
\hline \multirow[t]{2}{*}{$\mathrm{E} 3+2021$} & $\mathrm{CC}$ & 67.20 & 2.98 \\
\hline & CT & 65.82 & 3.08 \\
\hline
\end{tabular}

モン処理を行わなくても可能と考えられる。また、遺 伝的改良に扔いても、泌乳持続性を左右する遺伝子を 解析し、それらの情報をもとに遺伝子の多型の関与を 明らかにすれば、育種改良の精度や効率がさらに上昇 すると考えられる。

\section{3. 泌乳持続性という新しい選抜形質の特徴}

\section{3-1. 飼料の利用性}

泌乳持続性の向上は、飼養管理を容易にするだけで はなく、エネルギー効率そのものも向上させる可能性 がある。粗エネルギー効率と乳生産の遺伝相関は、 0.88 〜 0.95 (Korver 1988) と極めて高く、Veerkamp ら (1994) は、高遺伝能力群は、平均遺伝能力群よりも乳生産性 に対して高いエネルギー効率、濃厚飼料に対する高い 反応性を示すとした。現在の牛は、乳生産に重きを扮 いて改良を進めているが、自動的にエネルギー効率も 遺伝的に高めてきたのである。エネルギー摄取量の指 標となる形質として乾物摂取量が考えられる。乾物捸 取量の遺伝率は、酪農現場で $0.20 \sim 0.25$ 、研究所など の実験では、0.35〜0.45 と高い (Jensen ら 1995; Lee ら 1992; Persaud ら 1991; Svendsen ら 1994; Van Arendonk ら 1991; Veerkamp と Brotherstone 1997)。乳 量と乾物摂取量との遺伝相関は、0.44〜0.95 (Jensen ら 1995; Lee ら 1992; Persaud ら 1991; Van Arendonk ら 1991：Veerkamp と Brotherstone 1997）と高いが1ではな い。したがって、乳量のみの選抜による間接選抜では、 乳量の増加に対する乾物摂取量の改良効果は充分でな く、分婏後の要求エネルギーの $40 \sim 48 \%$ のしか充 たさない(Van Arendonk ら 1991)。このことから、乾物 
摂取量の改良のためには直接選抜を行う必要がある。 Van Arendonk ら (1991) は、粗飼料掑取量と 305 日乳量 との遺伝相関は、 0.55 と高く、粗飼料摄取量の遺伝率は、 0.46 と遺伝的関与が大きいことを示し、飼料攝取量の 中でも粗飼料摂取量の大小が乳量との相関を大きく し、今後の改良形質としての重要性を主張した。しか し、現実の牛群検定の場で (粗) 飼料摂取量を正確に広 範囲でとることは極めて難しい。飼料摂取量を直接改 良しなくても泌乳中に必要なエネルギーを充分に摂取 できる方法を考える必要がある。その一つの方法とし て、ピーク乳量を下げ、泌乳持続性を高めることで、 一日当たりのエネルギー要求量を摂取可能な量に抑え たうえに総乳量を高めるということが考えられる。

Dekkers ら (1998)は、初産牛 (図 2)、3 産牛 (図 3)の 泌乳持続性の高い牛と低い牛の乳期中の乾物摂取量曲 線と泌乳曲線を求めた。305日乳量は、持続性に関わ
らずいずれも初産牛で $6,000 \mathrm{~kg} 、 3$ 産牛で 7,500 kg を示 す。高持続性牛は実線、低持続性牛は破線、乳量のマー カーはロ、乾物摂取量はマーカーなしで示した。初産、 3 産いずれでも乾物摂取量と乳量の乘離をみると、乘 離は、低持続性牛の方が高持続性牛よりも大きい。こ のことは、高持続性牛においては、泌乳前期では体脂 肪からのエネルギー動員が少なく、低持続性牛は、泌 乳前期では体脂肪動員が多いことを示唆している。乳 生産に対する代謝エネルギーの利用効率は、一般に

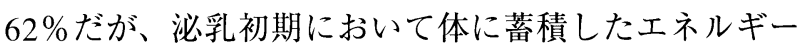
が乳生産に動員され、泌乳中後期に体重が回復する場 合、つまり、泌乳中後期にエネルギーを蓄積し、泌乳 初期に動員する経路をたどった場合の代謝エネルギー の産乳への利用効率は $52.6 \%$ と低い（日本飼養標準、 2006）。高持続性牛は、泌乳中後期での飼料エネルギー の蓄積、泌乳初期でのエネルギー動員という経路の関

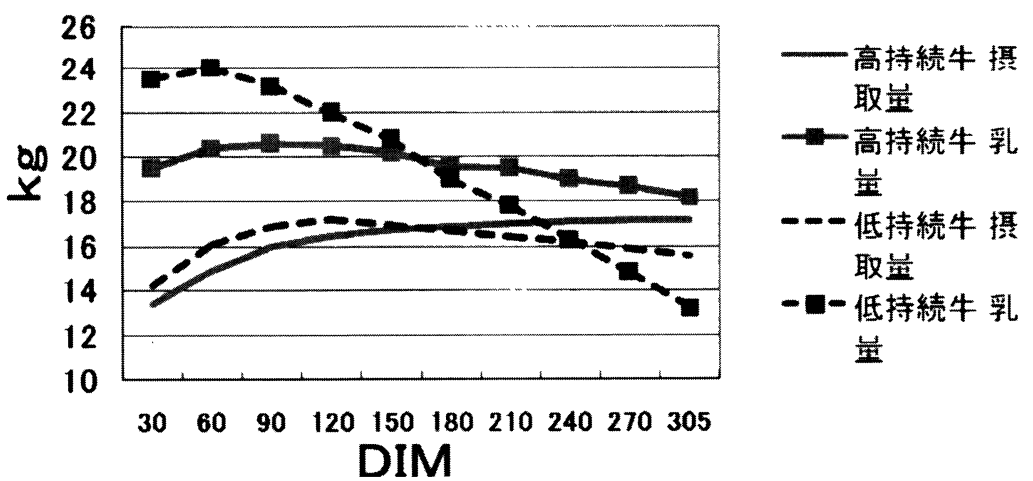

図 2. 初産牛における高及び低泌乳持続性牛の乾物掑取量と乳量 (305 日乳量 : $6,000 \mathrm{~kg})$

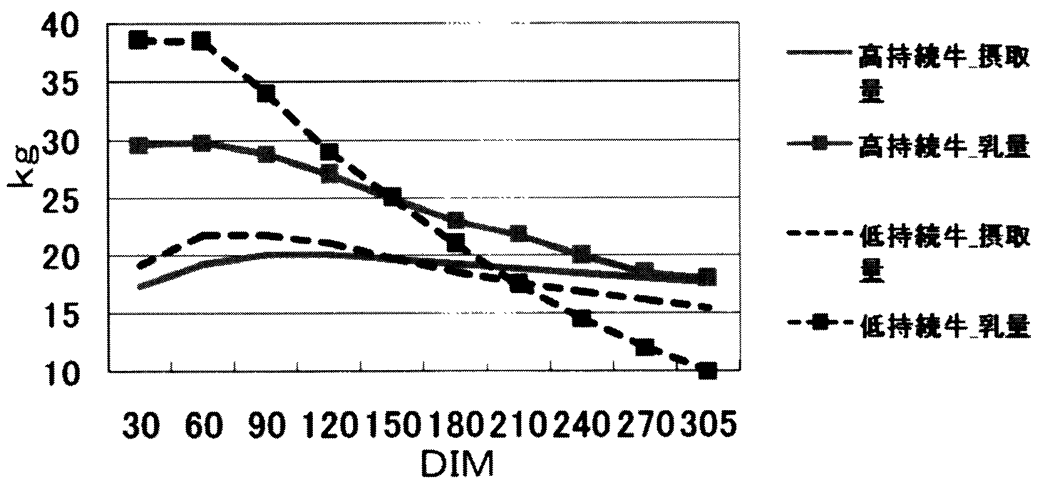

図 3. 3 産牛における高及び低泌乳持続性牛の乾物掑取量と乳量 (305 日乳量：7,500kg) 
与が低持続性牛より小さく、産乳に関してエネルギー 効率が高いと思われる。低持続性牛の泌乳後期の乳量 の大きな低下は、乳生産に必要な栄養量以上の栄養を 供給することになりやすく、分娩後の種々の問題の誘 因となる過肥を導きやすい。

Buckley ら (2000) は、アイルランドで、北米型の乳 牛を遺伝能力の大小で 2 群し、 3 月初めから 11 月下旬 まで、濃厚飼料補給下でペレニアルライグラスを主体 にした放牧試験を行い、粗飼料と総乾物摂取量を調べ た（表 4)。遺伝的にハイレベルな乳牛は、粗飼料摄取 量は平均遺伝レベル乳牛より高く、トータルとしての 乾物摂取量も高かった。このように粗飼料の食い込み 量の大小は乾物摂取量の大小に強く関連する。なお、 泌乳中後期は、泌乳前期に比べ日乳量は少ないので良 質粗飼料主体による乳生産は容易である。したがって、 泌乳持続性を高めることは、泌乳中後期において粗飼 料からの乳生産を主体として、粗飼料の利用性を高め
ることが出来ることを意味する。

高持続性牛の別な特徵は、泌乳曲線が乳期をとおし て平準化することである。したがって、ピーク乳量が $50 \sim 60 \mathrm{~kg}$ と大きくなく、その分、中後期の乳量が大 きくて総乳量をカバーする。ピーク乳量が小さいこと は、濃厚飼料の給与量が少なくてすむ (田鎖 2007)。 Sölkner と Fuchs (1987) は、高持続性牛における濃厚飼 料の節約を実証した(表 5)。305 日乳量が $10,000 \mathrm{~kg}$ の 泌乳曲線 (図 4)において、自給飼料から生産できる 1 日乳量を種々設定して、例えば $25 \mathrm{~kg}$ とすると 305 日 乳量生産に占める自給飼料から生産される乳量の割合 は、高、低持続性牛でそれぞれ 75.25、70.99\% と高持 続性牛の方が低持続性牛と比べ飼料自給率は、 $4 \%$ ほ ど高くなる(富樫 2007a)。こうして、より自給飼料利 用性の高い牛を提供し、今まで以上に食い込みのよい 良質な粗飼料を生産し、それを多く食べさせる飼養管 理技術、つまり良質な粗飼料から酢酸、プロピオン酸

表 4. 粗飼料 DM ( $\mathrm{kg} / \mathrm{cow} / \mathrm{day})$ と総 DM 摂取量 $(\mathrm{kg} / \mathrm{cow} / \mathrm{day})$

\begin{tabular}{|c|c|c|c|c|c|}
\hline 産 次 & 分婏後日数 & 摂 取 & $\mathrm{HG}^{\mathrm{a}}$ & $\mathrm{MG}^{\mathrm{a}}$ & 有意性 \\
\hline \multirow[t]{2}{*}{1} & 164 & $\mathrm{GDMI}^{\mathrm{b}}$ & 14.4 & 13.7 & $* * * \mathrm{c}$ \\
\hline & & TDMI $^{b}$ & 16.0 & 15.3 & $* * *$ \\
\hline \multirow[t]{2}{*}{2} & 161 & GDMI & 19.3 & 17.9 & $* * *$ \\
\hline & & TDMI & 20.5 & 19.1 & $* * *$ \\
\hline \multirow[t]{2}{*}{3} & 114 & GDMI & 18.0 & 16.4 & $* * *$ \\
\hline & & TDMI & 20.2 & 18.6 & $* * *$ \\
\hline
\end{tabular}

${ }^{\mathrm{a}} \mathrm{HG}$ : 高乳量群, $\mathrm{MG}$ : 平均乳量群.

${ }^{\mathrm{b}}$ GDMI : 粗飼料 DM 摂取量, TDMI：総 DM 摂取量。

$\mathrm{c} * * * \mathrm{P}<0.001$.

表 5. 乳量 $5,500 \mathrm{~kg}$ 乳牛における泌乳持続性が高い牛と低い牛の分婏後の濃厚飼料陉取量 $(\mathrm{kg})$

\begin{tabular}{lclc}
\hline 泌乳持続性 & 濃厚飼料摂取量 & 泌乳持続性 & 濃厚飼料摂取量 \\
\hline $1-100$ 日 & & $201-305$ 日 & \\
高 & 266 & 高 & 174 \\
低 & 442 & 低 & 85 \\
差 & -176 & 差 & +89 \\
& & & \\
$101-200$ 日 & & $1-305$ 日 & \\
高 & 220 & 高 & 659 \\
低 & 294 & 低 & 820 \\
差 & -74 & 差 & -161 \\
\hline
\end{tabular}




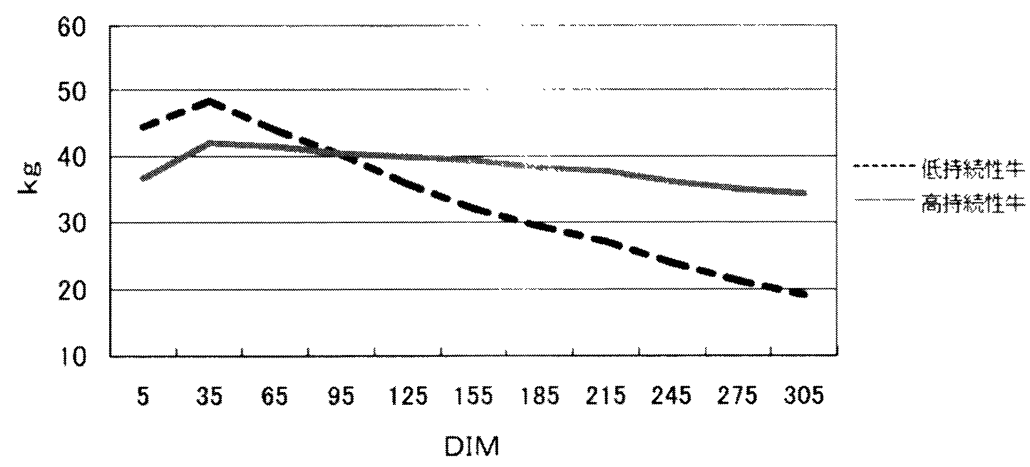

図 4. 乳量 1 万 $\mathrm{kg}$ の高泌乳持繶性牛と低泌乳持続性牛の泌乳曲線

表 6. 泌乳持続性、ピーク乳量日、初産 305 日乳量と経産牛の繁殖形質との遺伝相関

\begin{tabular}{lccc}
\hline & 泌乳持続性 & ピーク乳量日 & 初産 305 日乳量 \\
\hline NRRC & 0.32 & 0.11 & 0.02 \\
分婏間隔 & 0.17 & 0.31 & 0.51 \\
\hline
\end{tabular}

等のエネルギー、菌体たんぱくを多く生産させるとい う乳牛の本来の生理にあった技術を向上させることに よって、我が国の酪農がより足腰が強く、消費者に理 解される酪農になると思われる。乳期に伴う乳量の変 化が少ないので、飼料設計も極めて簡単になる。この ことは、エネルギー、たん白の過不足を少なくし、そ れらの要求量に対する充足率を高め、乳脂肪率、乳た ん白質率を向上させる (Sölkner と Fuchs 1987)。飼料設 計が極めて簡単になることは、残滓を少なくし、牛群 のグループ化も容易になる。特に、ピーク乳量が高く なく乳期を通じて乳量が平準化しているので、TMRの 飼料設計も容易になり、エネルギー価と同時に単価も 高い配合飼料成分だけでなく、カス類などの単価が比 較的安い配合飼料成分の利用も今まで以上に高めるこ とができょう。

\section{3-2. 繁殖や疾病の影響}

泌乳初期の負のエネルギーバランスが受胎性を低下 させる (Butler 2003)。特に、分婏後 28 日までの泌乳初 期の負のエネルギーバランスが受胎性を低下させる (Patton ら 2007)。負のエネルギーバランスは、卵胞の 初期発育を促進する IGF-1 分泌を低下させ、卵胞の初 期発育、その後の卵巣機能を低下させ、受胎性の低下 につながると思われる（Kawashima ら 2007）。原始卵胞
が発育、成熟し排卵にいたるには、60〜80 日かかる といわれ、授精時期が分婏後 $60 \sim 80$ 日の場合は、ま さに原始卵胞の初期発育が分娩後の負のエネルギーバ ランス時にあたり、負のエネルギーバランスの影響を 受けやすくなる。ここで、よく食う牛あるいはよく食 わせる飼養管理は、負のエネルギーバランスの影響を 少なくし繁殖の悪影響を少なくする。しかし、一般に 分婏前後の飼養管理は難しく現実には、受胎率の低下 や第 4 胃変位等の疾病を誘発しやすい。そこで、多く の酪農家が容易に分娩前後の飼養管理ができるような 牛あるいは飼養管理の開発が重要になる。その一つの 回答が「低ピーク高持続型乳生産」と思われる。乳量 と繁殖性とに望ましくない遗伝的な負の遺伝関倸が報 告 (Collard ら 2000; Jorritsma ら 2003; Pryce 2004)され ているが、大事なことは乳量に左右されにくい繁殖性 の良し覀しの直接的要因は何かということである。こ の回答が得られれば、たとえ高乳量であっても高い受 胎性が可能になる。その回答の一つとして、四 $2 \sim 3$ に示すように、305 日乳量が同じであっても、泌乳曲 線の違いによって高泌乳持続性牛は低泌乳持続性牛よ りも受胎性が高い可能性が考えられる。Muir ら (2004) は、泌乳持続性と分娩後 56 日までの受胎の有無を示 す NRRC との遺伝相関を 0.32 (表 6)、Bar-Anan と Ron (1985) は、泌乳持続性と受胎率の遺伝相関を 0.42 とし 
た。Wellerら (2006) は、泌乳持続性と受胎率の遺伝相 関を初産、2 産、それぞれで $0.2 、 0.10$ とした。 Kawashima ら (2007) は、分婏後 3 週間までに排卵した 牛と排卵しなかった牛のピークまでの乳量増加を調べ た結果、排卵群は、1.71 kg/day、無排卵群は、 $2.54 \mathrm{~kg} /$ day とピークまでの乳量の増加速度が遅い牛の方がエ ネルギー負荷が少なく排卵し易いことを示した。一般 に、低ピーク高持続型乳牛は、図 1 に示すようにピー クまでの乳量増加が遅く、ピークが低いとともにピー ク日が遅くなる (Muirら 2004) ので負のエネルギー負 荷が少なく、繁殖に有利に働くと思われる。

負のエネルギーバランスは、免疫システムを抑制する (Lyons ら 1991)。したがって、エネルギーバランスが 負になるほど乳房炎や子宮内膜炎等の感染症への感受 性がますと考えられる。山崎ら (2007) は、泌乳 30～ 100 日の乳房炎発症群と非発症群の分娩後 30 日までの 乳量増加速度を調べた所、非発症群は発症群より乳量 増加速度が小さいことを認めた。乳量増加速度が小さ いことは、負のエネルギー負荷が小さく、その結果、 乳房炎の発症が少なくなると思われる。Appuhamy ら （2007）は、泌乳持続性の 1 標準偏差上昇に伴う疾病罹 患率 (オッズ比)の減少を解析し、分婏後 100 日以降の 乳房炎の罹患は泌乳持続性の向上により初産、経産、 それぞれ $54 \%$ 、23\%減少させるとした。たた、 Jacobsen ら (2003) は、泌乳持続性と疾病のかかりやす さの遺伝相関を調べたが、マイナスの小さな值であり、 統計的には 0 と変わらず特に関係があるとはいえない とした。これは、疾病により泌乳曲線自体が変わるこ と、つまり代謝病にかかってしまったら本来遺伝的に もっているピーク乳量よりも少ない乳量、あるいは泌
乳中後期に疾病にかかってしまったら、その疾病によ り本来遺伝的にもっている乳量よりも低下し、結果と して泌乳持続性が低下してしまい、本来の牛自身が もっている乳量と疾病のかかり易さとの遺伝的関係の 解析が難しくなることによる。ただ、疾病になってし まった後の酪農現場での遺伝解析は難しいが、泌乳持 続性の高低 2 牛群を実験的に用意し、疾病の感受性を 調べれば回答が得られると思われ、負のエネルギー負 荷が小さい高泌乳持続性牛は疾病が少ないと期待され る。疾病や繁殖が影響する乳牛の在群期間と泌乳持続 性の遺伝相関は、初産、2 産、それぞれ 0.254、0.582 とプラスで泌乳持続性が牛群に存在する期間を長くさ せる(Weller ら 2006)。特に、2 産で值が大きかったこ とは、初産に比べピーク以降の低下が大きい 2 産の乳 量で、その低下を少なくすることが在群期間を長くで きることを意味する。Hadleyら（2006）は、アメリカ中 西部の乳牛の淘汰率効果を推定し、泌乳持続性は $-2.08 \%$ の効果、つまりより長く牛群に至らしめる形質 であることを示した。

\section{3-3. 放牧での泌乳持続性}

Zwald ら (2001) は、ニュージーランド、オーストラ リア、アメリカ、カナダ、イスラエルの乳量、搾乳期間、 ピーク乳量、ピーク日、泌乳持続性、初産分婏月齢を 示した (表 7)。放牧国ニュージーランドは、季節繁殖 を行い、草の多い雨季に泌乳最盛期がくるように、草 地の生産と泌乳曲線を合致させる生産システムであ る。放牧期間中に搾乳を行うことから、その長さは 220 日と他国と比べて最も短い。全ての個体で搾乳を、 放牧可能な季節にそろえるため、季節繁殖を行い、同

表 7. 各国の初産牛の㩁乳期間、乳量、ピーク、泌乳持続性 (240 日乳量 / 60 日乳量) 等

\begin{tabular}{lccccc}
\hline & オーストラリア & カナダ & イスラエル & ニュージーランド & アメリカ \\
\hline 搾乳期間 & 271 & 282 & 281 & 220 & 283 \\
平均乳量 $(\mathrm{kg})$ & 4805 & 7567 & 8850 & 3541 & 8329 \\
平均乳量 $(\mathrm{kg})$ の標準偏差 & 771 & 1057 & 1076 & 564 & 1189 \\
ピーク日 & 76 & 70 & 102 & 60 & 92 \\
ピーク乳量 & 21.1 & 28.4 & 31.4 & 17.1 & 30.5 \\
泌乳持続性: (240 日乳量/60 日乳量) & 0.68 & 0.78 & 0.9 & 0.59 & 0.86 \\
初産分婏月齢 & 27.1 & 27.7 & 24.2 & 24.2 & 26.7 \\
$\quad$ 脂肪/タンパク & 1.27 & 1.15 & 1.05 & 1.32 & 1.15 \\
種牛育種価 & 276 & 608 & 1742 & -474 & 1568 \\
(アメリカをベースにしたインターブル評価値) & 27 & & &
\end{tabular}


じ時期に分娩しなければならない。したがって、多く の牛が 24 ケ月齢で初産をむかえ、分婏間隔は、368日 （LIC 2003）であり、その後 1 年 1 産を繰り返す。ニュー ジーランドは他国に比べて、乳量と泌乳持続性が最も 小さい。ピーク日も一番早く、急激に乳量が低下する 低ピーク低持続型乳牛を示す。我が国でも、搾乳期間 中の飼養管理法の一つとして放牧が利用されている。 しかし、我が国の放牧管理はニュージーランドとは異 なり、完全な季節繁殖でなく、飼料も放牧草のみなら ずサイレージや若干の配合飼料も利用している。その ため、乳量が多い泌乳前期を牧草の成長が高い春に牛 群全てにおいてあわせる必要はなく、搾乳期間を放牧 草が充分にある季節に制限する必要もない。この方法 は、飼料の多くを放牧草のみに依存した搾乳期間が短 い乳生产よりも、放牧を主体としながら良質な自給䝶 蔵粗飼料も利用して搾乳期間を長くした現実的な放牧 システムと思われる。搾乳期間が長いので、当然、乳 量は多くなる。しかし、放牧草が少ない季節に泌乳盛 期となる個体が多ければ、補助飼料を多給する必要が あり、放牧による省力化のメリットが小さくなる。一 方、低ピーク高泌乳持続型の乳牛を放牧に用いること ができれば、年間を通して群の飼料要求量の変化が小 さくなると考えられ、現在よりも、より計画的で、省 力的、効率的な放牧管理が可能となることが期待され る。

\section{4. 泌乳持続性の遺伝的特性と高泌乳持続性牛の作出法}

泌乳持続性の表示は多々あるが、305 日乳量と泌乳 持続性を同時に改良するには、(泌乳中後期乳量/泌 乳前期乳量) あるいは (280日乳量/ピーク乳量)を選 抜形質にするのがふさわしいが、泌乳持続性そのもの を改良するには、(280日乳量ーピーク乳量)など差を
選抜形質としたほうが改良効果は大きい(Togashi と Lin 2004a)。総乳量は、乳牛にとって必須な選抜形質 であり必ず選抜形質に含める必要がある。総乳量と泌 乳持続性の改良に対する期待 (重み)を種々変えてそ れにふさわしい選抜式を求める際は、総乳量と泌乳持 続性の特性を合わせ持つ (泌乳中後期乳量 / 泌乳前期 乳量) あるいは (280日乳量/ピーク乳量)を選抜形質 として扱わず、総乳量と泌乳持続性を別々の形質とし てとらえた方がよい。つまり、泌乳持続性を(280日乳 量 -ピーク乳量)、総乳量は (305 日乳量) として選抜形 質に別々に入れる方が総乳量と泌乳持続性を同時に改 良したときの改良効果が大きい。Togashi ら(2008a)は、 初産、2 産、3 産に扔ける泌乳持続性の遺伝率は、0.15、 $0.39 、 0.38$ と泌乳持続性が低い $2 、 3$ 産牛で高く、今 後の育種改良による泌乳持続性向上の可能性を示し た（表 8)。さらに、初産、2、3 産の泌乳持続性の遺伝 相関は、0.38〜0.75 と高く、お互いの泌乳持続性を高 め得ることを示した。図 5 に従来型の初産 305 日乳量 選抜による初産時における選抜量の推移を示した。泌 乳前期から後期までほぼ一様に増加する。つまり、現 状の選抜を続ける限り泌乳前期の乳量は上がり続け、 今よりもさらに、負のエネルギー負荷が増大すること を意味している。しかし、初産の泌乳持続性と $1 、 2 、$ 3 産の 305 日乳量とは $0.46 \sim 0.51 、 2$ 産の泌乳持続性

\section{表 8. 泌乳持続性の遺伝率と遺伝相関}

\begin{tabular}{llll}
\hline & 初産 & 2 産 & 3 産 \\
\hline 初産 & 0.15 & 0.75 & 0.5 \\
2 産 & & 0.39 & 0.78 \\
3 産 & & & 0.38 \\
\hline
\end{tabular}

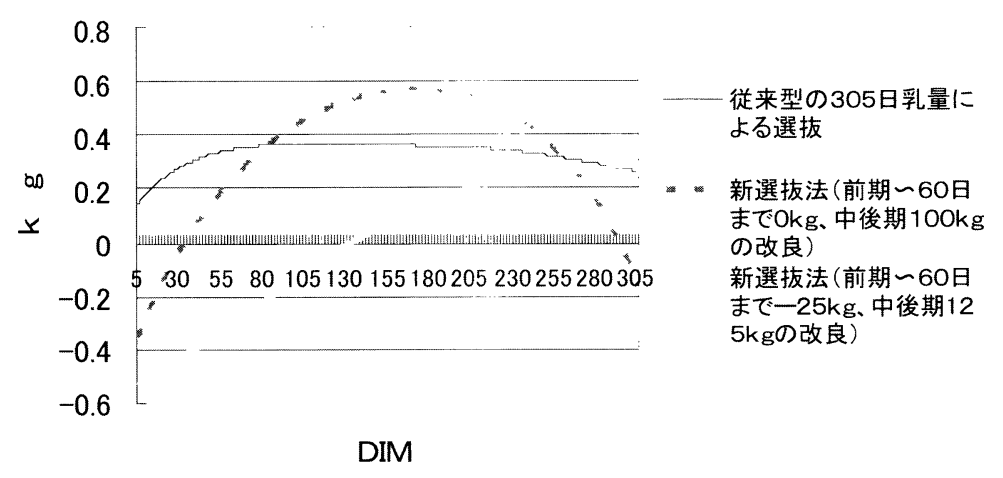

図 5. 泌乳曲線による選抜式の㩁乳㩁乳日毎の改良量 
と 1、2、3 産の 305 日乳量とは $0.13 \sim 0.34 、 3$ 産の泌 乳持続性と $1 、 2 、 3$ 産の 305 日乳量とは $0.12 \sim 0.27$ と正の值を示した (Togashi ら 2008a)。このことから、 泌乳持続性と 305 日乳量を同時に改良することが可 能であると考えられた。特に初産の泌乳持続性と $1 、 2 、$ 3 産の 305 日乳量との遺伝相関は高く、初産の泌乳持 続性は $1 、 2 、 3$ 産の生涯にわたる乳量の増加に貢献 する。Togashi とLin (2004b) は、初産時における泌乳 前期の乳量をこれ以上あげずに、初産乳量の改良をむ しろ泌乳中後期に移す選抜法を開発した（図 5)。これ は、ピーク乳量をこれ以上あげずに、そのかわり泌乳 持続性をあげて泌乳中後期の乳量増加を可能にする 選抜法である。実際、乳量も泌乳持続性も高い種雄牛 は存在する（表 9)。さらに Togashi と Lin (2007b) は、 泌乳曲線の遺伝特性のうち、泌乳持続性に関する成分 のみを抽出する方法を開発し、それを用いて選抜を行 うことで、効率的に泌乳持続性があがることを示した。 また、Togashi と Lin (2008b) は、初産のみならず1、2、
3 産の泌乳曲線において泌乳前期乳量より、泌乳中後 期乳量を大きく改良する選抜法として、1、2、3 産の 総乳量と泌乳持続性 (280日乳量 -ピーク乳量) を選抜 形質とする選抜法を開発した（図 6)。これによって、 多産次に渡って、泌乳前期の乳量を抑えながら、総乳 量と受胎率の低下や疾病発生を抑制することが期待で きる。

\section{5. 泌乳持続性と乾乳期間の短縮}

2 ヶ月の乾乳期間が、㕕く浸透しているが最近、乾 乳期間の短縮により分婏後の負のエネルギー負荷を少 なくし、繁殖や疾病の問題を解決する技術が開発され てきた (Rastani ら 2005)。実験的に 30 日に乾乳期間を 短くしても泌乳量には影響ないという報告もある (Gulay ら 2003)。Rastani ら (2005) は、乾乳期間 0、 28、56 日間の乾乳処理の乳量、乾物摂取量を調べた (図 7、8）。0、28 日乾乳は、泌乳初期の乳量は少なく低ピー ク型の乳量曲線を示した。乾乳期間の短縮は、繁殖や

表 9. 初産の乳量成續に基づく選抜指数式值による高および低泌乳持続性種雄牛

\begin{tabular}{|c|c|c|c|c|c|}
\hline \multicolumn{3}{|c|}{ 高持続性雄牛 } & \multicolumn{3}{|c|}{ 低持続性雄牛 } \\
\hline 種雄牛 & 305 日乳量 $(\mathrm{kg})$ & $\begin{array}{c}\text { 前期 - 後期 } \\
\text { 平均日乳量の差 }(\mathrm{kg})\end{array}$ & 種雄牛 & 305 日乳量 (kg) & $\begin{array}{c}\text { 前期 - 後期 } \\
\text { 平均日乳量の差 }(\mathrm{kg})\end{array}$ \\
\hline A & $8,242.1$ & 0.42 & $\mathrm{H}$ & $7,595.3$ & 4.45 \\
\hline B & $9,223.9$ & 1.22 & I & $7,806.7$ & 4.61 \\
\hline $\mathrm{C}$ & $8,529.5$ & 1.05 & $\mathrm{~J}$ & $7,919.4$ & 4.80 \\
\hline $\mathrm{D}$ & $8,515.7$ & 1.18 & $\mathrm{~K}$ & $8,328.1$ & 5.02 \\
\hline E & $8,097.9$ & 1.01 & $\mathrm{~L}$ & $8,750.1$ & 5.29 \\
\hline $\mathrm{F}$ & $8,534.4$ & 1.30 & M & $8,081.0$ & 5.75 \\
\hline
\end{tabular}

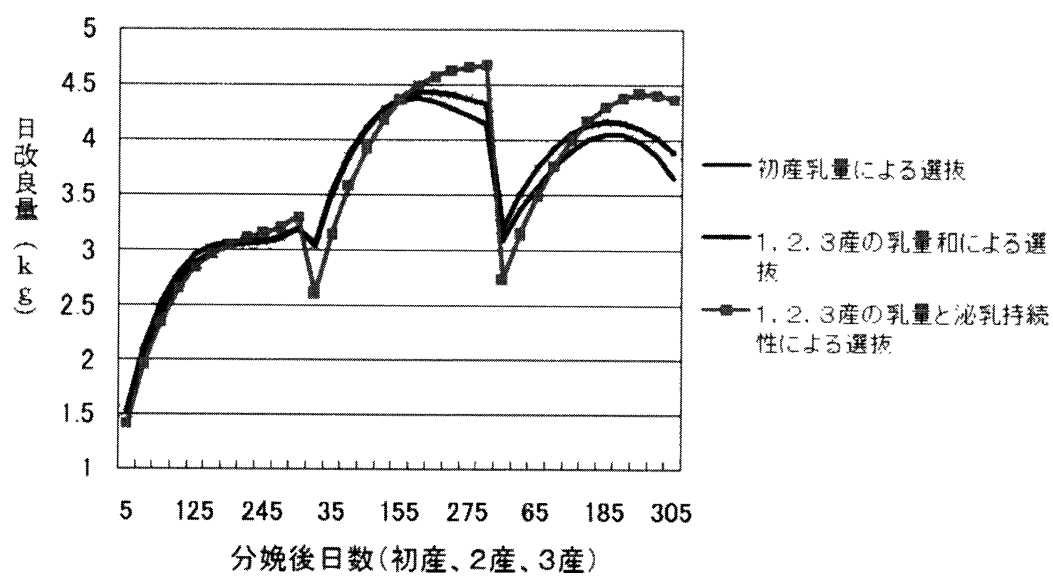

図 6. 1，2，3 産の泌乳前期から中後期に改良量を変える選抜法 


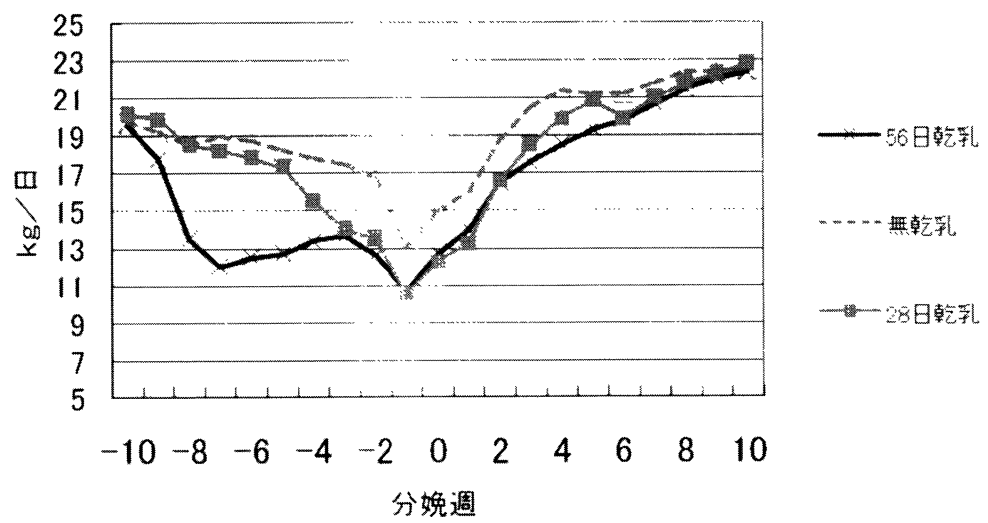

図 7. 分婏前後の乾物掑取量

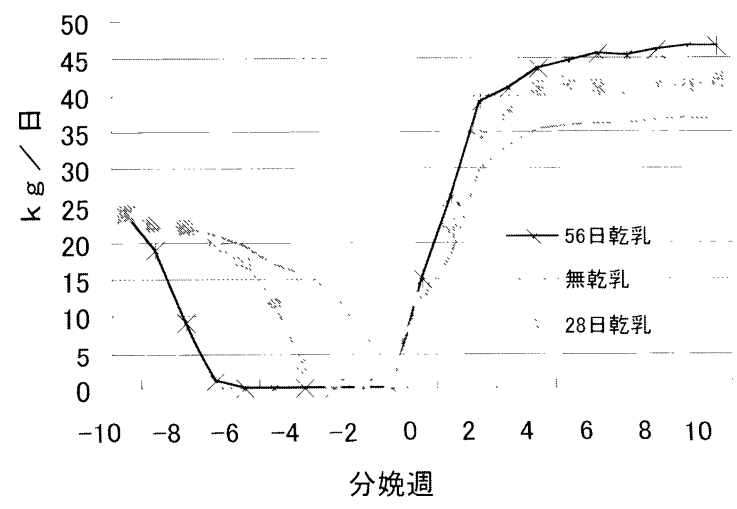

図8. 分婏前後の乳量

表 10.アメリカ DHI における㩁乳日数が 700 日以上の牛の記録 (初産後㩁乳継続)

\begin{tabular}{ccrccc}
\hline 搾乳年数 & 搾乳期間 & 搾乳牛数 & 乳量 $(\mathrm{kg})$ & 一日当たり乳量 $(\mathrm{kg} /$ 日 $)$ & 検定最終日乳量 $(\mathrm{kg} /$ 日 $)$ \\
\hline 2.0 & $700 \sim 790$ & 2110 & 21,320 & 28.9 & 20.2 \\
2.5 & $853 \sim 973$ & 848 & 25.399 & 28.0 & 20.7 \\
3.0 & $1035 \sim 1155$ & 129 & 30,474 & 28.3 & 20.5 \\
3.5 & $1218 \sim 1338$ & 74 & 35,769 & 28.0 & 22.4 \\
4.0 & $1400 \sim 1520$ & 26 & 39.032 & 26.9 & 21.6 \\
\hline
\end{tabular}

疾病の問題を解決する技術としてのみならず乾乳期間 のえさ管理を従来、2 あるいは 3 期に分けて飼養して いたのを分婏後の飼料成分に近い飼料でも30日間と 短くすることで過肥を導くことなく単純な飼料管理に すること、30日と乾乳期間が短くなるので乾乳舎に収 容する頭数の集中を減らす効果がある。ただ、初産牛 は乳腺の成育途中であることから乾乳期の短縮は必ず しも適切ではなく、経産牛や受胎しにくい牛の繁殖や
疾病対策としての一つの選択すべき技術と思われる。 一方、乾乳期間の短縮は、泌乳中後期の乳量の低下を 少なくする泌乳持続性が確保されないと低ピーク低総 乳量に終わる危険性がある。したがって、乾乳期間の 短縮技術と併行して泌乳持続性をあげなければならな い。な㧍、泌乳中後期の乳量レベルは泌乳前期に比べ れば低いので、前述したように改良以外にも良質粗飼 料を中心にした飼料調整で乳量をアップし、泌乳持続 
性をあげることができよう。

泌乳持続性と乾乳期間の短縮 (2ケ月から 1 ケ月) は、 1 年 1 産に限った場合でも搾乳期間が 1 ケ月延長され、 純粋に乳量の増加となり収益を向上させる。泌乳持続 性が高い牛は、 1 年 1 産に固定せずに、従来のように 日乳量が一定量以下、例えば、 $20 \mathrm{~kg}$ 以下になる時点ま で搾乳を続け、搾乳期間を延長できる。乳牛の一生に おいて空胎期間が大きくなること、つまり分婏間隔が 大きくなるにつれて生涯乳量が減少する (Meadows ら 2005)。しかし、Dekkers ら (1998)、De Vries (2006)が 指摘するように牛の泌乳持続性という新しい形質が最 適な分娩間隔、最適な授精時期に大きく影響する。 Rotzら (2005) は、アメリカにおいて搾乳日数が 700 日 以上の記録を調へ、 1 年 1 産に限らず初産後、泌乳持 続性が高く700〜1,500 日も連続して搾乳している牛 を報告している（表 10）。なお、我が国の最近の高泌 乳牛にとって、最適な分婏間隔、授精時期を、乳価、 乳量水準、後継牛価格、淘汰牛価格、飼料費のみなら ず新しい形質である泌乳持続性を考慮して、経営的に 最適な授精時期や分婏間隔が今後、検討される必要が ある。

「低ピーク高持続型乳生産」に関する選抜指標を育種 が提示し、育種、遺伝、栄養、繁殖、飼養管理等の全 分野が一緒になって具体的な「低ピーク高持続型乳生 産」技術を構築し、自給飼料利用型の足腰の強い、消 費者に理解される酪農を構築していく必要があろう。

\section{6. 引用文献}

Appuhamy JADRN, Cassell BG, Dechow CD, Cole JB. 2007. Phenotypic relationships of common health disorders in dairy cows to lactation persistency estimated from dairy milk weights. Journal of Dairy Science, 90: 4424-4434.

Athie F, Bachman KC, Head HH, Hayen MJ, Wilcox CJ. 1996. Estrogen administered at final milk removal accelerates involution of bovine mammary gland. Journal of Dairy Science, 79: 220-226.

Athie F, Bachman KC, Head HH, Hayen MJ, Wilcox CJ. 1997. Milk plasmin during bovine mammary involution that has been accelerated by estrogen. Journal of Dairy Science, 80: $1561-1568$.

Bachman KC, Hayen MJ, Morse D, Wilcox CJ. 1988. Effect of pregnancy, milk yield, and somatic cell count on bovine milk fat hydrolysis. Journal of Dairy Science, 71: 925-931.
Bar-Anan R, Ron M. 1985. Association among milk yield, yield persistency, conception, and culling of Israeli Holstein dairy cattle. Journal of Dairy Science, 68: 382-386.

Bar-Peled U, Maltz E, Bruckental I, Folman Y, Kali Y, Gacitua H, Lehrer AR, Knight CH, Robinzon B, Voet H, Tagari H. 1995. Relationship between frequent milking or suckling in early lactation and milk production of high producing dairy cows. Journal of Dairy Science, 78: 2726-2736.

Bauman DE, Everett RW, Weiland WH, Collier RJ. 1999. Production responses to bovine somatotropin in northeast dairy herds. Journal of Dairy Science, 82: 2564-2573.

Beckman JS, Ye YZ, Anderson PG, Chen J, Accavitti MA, Tarpey MM, White CR. 1994. Extensive nitration of protein tyrosine in human atherosclerosis detected by immunohistochemistry. Biological Chemistry Hoppe Seyler, 375: 81-88.

Buckley F, Dillon P, Crosse S, Flynn F, Rath M. 2000. The performance of Holstein Friesian dairy cows of high and medium genetic merit for milk production on grassbased feeding systems. Livestock Production Science, 64: $107-119$.

Butler WR. 2003. Energy balance relationships with follicular development, ovulation and fertility in postpartum dairy cows. Livestock Production Science, 83: $211-218$.

Capuco AV, Akers RM. 1990. Thymidine incorporation by lactation mammary epithelium during compensatory mammary growth in beef cattle. Journal of Dairy Science, 73: 3094-3103.

Capuco AV, Akers RM, Smith JJ. 1997. Mammary growth in Holstein cows during the dry period: quantification of nucleic acids and histology. Journal of Dairy Science, 80: 477-487.

Capuco AV, Byatt JC. 1998. Cell turnover in the mammary gland. Journal of Dairy Science, 81(Suppl.1): 224.

Capuco AV, Wood DL, Baldwin R, Mcleod K, Paape MJ. 2001. Mammary cell number, proliferation, and apoptosis during a bovine lactation: relation to milk production and effect of bST. Journal of Dairy Science, 84: $2177-2187$.

Capuco AV, Ellis SE, Hale SA, Long E, Erdman RA, Zhao X, Paape MJ. 2003. Lactation persistency: Insights 
from mammary cell proliferation studies. Journal of Animal Science, 81(Suppl.3): 18-31.

Collard BL, Boettcher PJ, Dekkers JCM, Petitclerc D, Schaeffer LR. 2000. Relationships between energy balance and health traits of dairy cattle in early lactation. Journal of Dairy Science, 83: 2683-2690.

Dahl GE, Elsasser TH, Capuco AV, Erdman RA, Peters RR. 1997. Effects of a long daily photoperiod on milk yield and circulating concentrations of insulin-like growth factor-1. Journal of Dairy Science, 80: 2784-2789.

Dahl GE, Buchanan BA, Tucker HA. 2000. Photoperiodic effects on dairy cattle: A review. Journal of Dairy Science, 83: 885-893.

Dekkers JCM, Ten Haag JH, Weersink A. 1998. Economic aspects of persistency of lactation in dairy cattle. Livestock Production Science, 53: 237-252.

De Vries A. 2006. Economic value of pregnancy in dairy cattle. Journal of Dairy Science, 89: 3876-3885.

Esteve JM, Mompo J, Garcia de la, Asuncion J, Sastre J, Asensi M, Vina JR, Vina J, Pallardo FV. 1999. Oxidative damage to mitochondrial DNA and glutathione oxidation in apoptosis: studies in vivo and in vitro. FASEB Journal, 13: 1055-1064.

Flint DJ, Tonner E, Knight CH, Whitelaw CBA, Webster J, Barber M, Allan G. 2001. Control of mammary involution by insulin-like growth factor binding proteins: role of prolactin. Livestock Production Science, 70: 115-120.

Gallego MI, Binart N, Robinson GW, Okagaki R, Coschigano KT, Perry J, Kopchick J, Oka T, Kelly PA, Hennighausen L. 2001. Prolactin, growth hormone, and epidermal growth factor activate stat 5 in different compartments of mammary tissue and exert different and overlapping developmental effects. Developmental Biology, 229: 163-175.

Gulay MS, Hayen MJ, Bachman KC, Belloso T, Liboni M, Head HH. 2003. Milk production and feed intake of Holstein cows given short (30-d) or normal (60-d) dry periods. Journal of Dairy Science, 86: 2030-2038.

Hadley GL, Wolf CA, Harsh SB. 2006. Dairy cattle culling patterns, explanations, and implications. Journal of Dairy Science, 89: 2286-2296.

Hadsell DL, Bonnette SG, Lee AV. 2002. Genetic manipulation of the IGF-I axis to regulate mammary gland development and function. Journal of Dairy
Science, 85: 365-377.

Harder B, Bennewitz J, Reinsch N, Thaller G, Thomsen H, Kühn C, Schwerin M, Erhardt G, Förster M, Reinhardt F, Kalm E. 2006. Mapping of quantitative trait loci for lactation persistency traits in German Holstein dairy cattle. Journal of Animal Breeding and Genetics, April; 123(2): 89-96.

Hochman A, Sternin H, Gorodin S, Korsmeyer S, Ziv I, Melamed E, Offen D. 1998. Enhanced Oxidative stress and altered antioxidants in brains of Bcl-2-deficient mice. Journal of Neurochemistry, 71: 741-748.

Hockenbery DM, Oltvai ZN, Yin XM, Milliman CL, Korsmeyer SJ. 1993. Bcl-2 functions in an antioxidant pathway to prevent apoptosis. Cell, 75: 241-251.

Hulboy DL, Rudolph LA, Matrisian LM. 1997. Matrix metalloproteinases as mediators of reproductive function. Molecular Human Reproduction, 3: 27-45.

Jacobsen JH, Rekaya R, Jensen J, Sorensen DA, Madsen P, Gianola D, Christensen LG, Pedersen J. 2003. Bayesian estimates of covariance components between lactation curve parameters and disease liability in Danish Holstein cows. Journal of Dairy Science, 86: 3000-3007.

Jensen J, Hohenboken WD, Madsen P, Andersen BB. 1995. Sirexnutrition interactions and genetic parameters for energy intake, production and efficiency of nutrient utilization in young bulls, heifers and lactation cows. Acta Agricultræ Scandinavica. Section A, Animal Science, 45: 81-91.

Jerry DJ, Dickinson ES, Roberts AL, Said TK. 2002. Regulation of apoptosis during mammary involution by the p53 tumor suppressor gene. Journal of Dairy Science, 85: 1103-1110.

Jorritsma R, Wensing T, Kruip K, Vos P, Noordhuizen J. 2003. Metabolic changes in early lactation and impaired reproductive performance in dairy cows. Veterinary Research, 34: 11-26.

Kawashima C, Amaya Montoya C, Masuda Y, Kaneko E, Matsui M, Shimizu T, Matsunaga N, Kida K, Miyake Y-I, Suzuki M, Miyamoto A. 2007. Short communication: A positive relationship between the first ovulation postpartum and the increasing ratio of milk yield in the first part of lactation in dairy cows. Journal of Dairy Science, 90: 2279-2282.

Kawashima C, Fukihara S, Maeda M, Kaneko E, Montoya 
CA, Matsui M, Shimizu T, Matsunaga N, Kida K, Miyake YI, Schams D, Miyamoto A. 2007. Relationship between metabolic hormones and ovulation of dominant follicle during the first follicular wave postpartum in high-producing dairy cows. Reproduction, 133: 155-163.

河原孝吉・後藤裕作・萩谷功一 鈴木三義・曽我部道彦. 2002. 北海道のホルスタイン集団において不完全 な血縁を利用した近交係数の算出および産乳能力 の近交退化と育種価への影響. 日本畜産学会報, 73: 249-259.

Knight CH, Peaker M. 1984. Compensatory increases in milk yield after hemimastectomy in lactation goats. Proceeding of the Physiological Society, 6: 36.

Knight CH. 2000. The importance of cell division in udder development. Livestock Production Science, 66: $169-176$.

Korver S. 1988. Genetic aspects of feed intake and feed efficiency in dairy cattle: a review. Livestock Production Science, 20: 1-13.

Lee AJ, Boichard DA, McAllister AJ, Lin CY, Nadarajah K, Batra TR, Roy GL, Vesely JA. 1992. Genetics of growth, feed intake, and milk yield in Holstein cattle. Journal of Dairy Science, 75: 3145-3154.

LIC. Dairy statistics. 2003. Livestock Improvement Corporation, Hamilton, New Zealand, 2002-2003.

Lyons DT, Freeman AE, Kuck AL. 1991. Genetics of health traits in Holstein cattle. Journal of Dairy Science, 74: 1092-1100.

Meadows C, Rajala-Schltz PJ, Frazer GS. 2005. A spreadsheet-based model demonstrating the nonuniform economic effects of varying reproductive performance in Ohiodairy herds. Journal of Dairy Science, 88: $1244-1254$.

Miller RH, Clay JS, Norman HD. 2001. Relationship of somatic cell score with fertility measures. Journal of Dairy Science, 84: 2543-2548.

Muir BL, Fatehi J, Schaeffer LR. 2004. Genetic relationships between persistency and reproductive performance in first-lactation Canadian Holstein. Journal of Dairy Science, 87: 3029-3037.

農業・食品産業技術総合研究機構. 2007. 日本飼養標 準乳牛. 2006 年版. 11, 中央畜産会, 東京.

Patton J, Kenny DA, McNamara S, Mee JF, Mara FPO', Diskin MG, Murphy JJ. 2007. Relationships among milk production, energy balance, plasma analytes, and reproduction in Holstein-Friesian cows. Journal of Dairy Science, 90: 649-658.

Persaud P, Simm G, Hill WG. 1991. Genetic and phenotypic parameters for yield, food intake and efficiency of dairy cows fed ad libitum. 1. Estimates for total measures and their relationship with live weight traits. Animal Production, 52: 435-444.

Phipps RH, Madakadze D, Mutsvangwa T, Hard DL, Dekerchove G. 1991. Use of bovine somatotropin in the tropics: the effect of sometribove on milk production of Bos indicus, dairy crossbred and Bos Taurus cows in Zimbabwe. Journal of Agricultural Science, 117: 257-263.

Pryce JE, Royal MD, Garnsworthy PC, Mao IL. 2004. Fertility in the high-producing dairy cow. Livestock Production Science, 86: 125-135.

Radi R, Beckman JS, Bush KM, Freeman BA. 1991. Peroxynitrite induced membrane lipid peroxidation. The cytotoxic potential of superoxide and nitric oxide. Archives of Biochemistry and Biophysics, 228: $481-487$.

Rastani RR, Grummer RR, Bertics SJ, Gumen A, Wiltbank MC, Mashek DG, Schwab MC. 2005. Reducing dry period length to simplify feeding transition cows: Milk production, energy balance, and metabolic profiles. Journal of Dairy Science, 88: 1004-1014.

Rotz CA, Zartman DL, Crandall KL. 2005. Economic and environmental feasibility of a perennial cow dairy farm. Journal of Dairy Science, 88: 3009-3019.

Sharma BS, Leyva I, Schenkel F, Karrow NA. 2006. Association of toll-like receptor 4 polymorphisms with somatic cell score and lactation persistency in Holstein bulls. Journal of Dairy Science, 89: 3626-3635.

Sinowatz F, Schams D, Kolle S, Plath A, Lincoln D, Waters MJ. 2000. Cellular localization of $\mathrm{GH}$ receptor in the bovine mammary gland during mammogenesis, lactation and involution, Journal of Endocrinology, 166: $503-510$.

Sölkner J, Fuchs W. 1987. A comparison of different measures of persistency with special respect to variation of test-day milk yields. Livestock Production Science, 16: 305-319.

Sorensen A, Sorensen MT, Anderson JB, Ingvartsen KL, Sejrsen K. 2000. Effect of milking frequency and diet 
on mammary development in lactation dairy cows. Abstracts of the 51st Annual Meeting of the European Association for Animal Production, 234.

Stefanon B, Colitti M, Gabai G, Knight CH, Wilde CJ. 2002. Mammary apoptosis and lactating persistency in dairy animals. Journal of Dairy Research, 69: 37-52.

Svendsen M, Skipenes P, Mao IL. 1994. Genetic correlations in the feed conversion complex of primiparous cows at a recommended and a reduced plane of nutrition. Journal of Animal Science, 72: $1441-1449$.

田鎖直澄. 2007. 乾乳期間の短縮による周産期ストレ 又回避技術。北海道地域確立農業検討会資料, $69-78$.

Togashi K, Lin CY. 2004a. Efficiency of different selection criteria for persistency and lactation milk yield. Journal of Dairy Science, 87: 1528-1535.

Togashi K, Lin CY. 2004b. Development of an optimal index to improve lactation yield and persistency with the least selection intensity. Journal of Dairy Science, 87: 3047-3052.

富樫研治. 2007a. 泌乳曲線の平準化による自給飼料活 用型乳牛への育種改良. 畜産の研究, 61: 96-102.

Togashi K, Lin CY. 2007b. Genetic modification of the lactation curve by bending the eigenvectors of the additive genetic random regression coefficient matrix. Journal of Dairy Science, 90: 5753-5758.

Togashi K, Lin CY, Atagi Y, Hagiya K, Sato J, Nakanishi T. 2008a. Genetic characteristics of Japanese Holstein cows based on multiple lactation random regression test-day animal models. Livestock Science, 114: 194-201.

Togashi K, Lin CY. 2008b. Genetic improvement of total milk yield and total lactation persistency of the first three lactations in dairy cattle. Journal of Dairy Science, accepted.

Van Amburgh ME, Galton DM, Bauman DE, Everett RW. 1997. Management and economics of extended calving intervals with use of bovine somatotropin. Livestock Production Science, 50; 15-28.

Van Arendonk JAM, Nieuwhof GJ, Vos H, Korver S. 1991. Genetic aspects of feed intake and efficiency in lactating dairy heifers. Livestock Production Science, 29: $263-275$.

Veerkamp RF, Simm G, Oldham JD. 1994. Effects of interaction between genotype and feeding system on milk production, feed intake, efficiency and body tissue mobilization in dairy cows. Livestock Production Science, 39: 229-241.

Veerkamp RF, Brotherstone S. 1997. Genetic correlations between linear type traits, food intake, live weight and body condition score in Holstein Friesian dairy cattle. Animal Science, 64: 385-392.

Weller JI, Ezra E, Leitner G. 2006. Genetic analysis of persistency in the Israeli Holstein population by the multitrait animal model. Journal of Dairy Science, 89: 2738-2746.

Wilde CJ, Henderson AJ, Knight CH, Blatchford DR, Faulkner A, Vernon RJ. 1987. Effects of long-term thrice-daily milking on mammary enzyme activity, cell population and milk yield. Journal of Animal Science, 64: $533-539$.

山崎武志 - 武田尚人 - 西浦明子 - 別府哲朗 - 笹井洋二 · 須田芳人 ·菅原真子・萩谷功一 - 佐分淳一. 2007. ホルスタイン初産牛における泌乳パターンと疾病 発症との間の関連性. 日本畜産学会第 107 回大会 講演要旨, 63 .

Yang J, Kennelly JJ, Baracos VE. 2000. The activity of transcription factor stat5 responds to prolactin, growth hormone and IGF-I in rat and bovine mammary explant culture. Journal of Animal Science, 78: 3114-3125.

Young CW, Seykora AJ. 1996. Estimates of Inbreeding and Relationship Among Registered Holstein Females in the United States. Journal of Dairy Science, 79: 502-505.

Zwald NR, Weigel KA, Flkse WF, Rekaya R. 2001. Characterization of dairy production systems in countries that participates in the International bull evaluation service. Journal of dairy Science, 84: 2530-2534. 